\title{
Serious Games as a Tool to Change People Attitudes: Analysis Based on the Discourse of Collective Subject
}

\author{
Fernanda P. Mota, Silvia S. C. Botelho, Diana F. Adamatti \\ Universidade Federal do Rio Grande, Brazil
}

\begin{abstract}
Educational processes are under constant change over the years, boosted by techniques and tools that come with the intention of adding ways to improve the absorption of knowledge presented, and also provide more effective, dynamic and diverse forms of learning. Games can facilitate the cognition, develop skills and beliefs on topics through practical experimentation, eliminating the need for tactile features that were necessary for the study of the processes involved in real environments. The Discourse of Collective Subject aims to show a thought or collective opinion from a group, based on a qualitative condition (individual opinions) and quantitative (group ideas). In this paper presents a qualitative study about the game influence in people life and how games can change the attitudes of them. To do this analysis, we have conduct interviews with students and their answers were tabulated using the Discourse of Collective Subject technique. Our conclusions are that $t$ games are in daily life of these students, as an entertainment, making decisions without any damage. Therefore, games are efficient tools to learn about serious things, besides they promote interaction and participation, and they help in cognitive skills. Thereby, we can conclude that games can help to change attitudes.
\end{abstract}

\section{Introduction}

Nowadays, the use of computers in education is diverse, interesting and challenging than simply transmitting information to the learner. The computer can also be used to improve learning environments and help students in their knowledge construction process. ProInfo (National Programme for Information Technology in Education) is a program developed by the MEC (Ministry of Education and Culture - Brazil) to introduce the computer and telecommunications technologies - telematics - in Public School [1]. The aim of this programme is that students acquire computational concepts such as computer operating principles, programming concepts and implications of computer in society. This approach was highly reported in the United States as "computer literacy" and it was the solution that many schools in Brazil to insert the computer in the teaching-learning process. Therefore, the curriculum was increased in the "Introduction to
Computer Science" course, which aims to teach computing to the student to have access to the computer. However, from an educational point of view, it has not changed the way the content of other subjects are taught [2].

However, computing goes across the use of computers for performing routine activities such as access to Internet (social networking, games, etc.) and produce texts. The computer can be used to develop new programs or games with different features, an activity that involves logic programming skills that can be applied in several areas, not limited to computers. The integration of programming logic in the basic and technical education can help to solve problems in a structured and rational way. The insertion of this new knowledge can make it visible to the students the role of sciences in development [1].

One of the main ways to access the world of technology to children and teenagers is the digital game because they the first contact usually are with electronic equipment, through a video game [3]. Games can be seen as a way to help students and teachers in the teaching and learning process (called as "serious games"). One of the goals is to provide educational games means of production and construction of knowledge by the student [4].

Piaget [5] uses the term "game" in a large sense and he affirms that this is not just a form of entertainment as well as it helps and enhances intellectual development. The author considers that the games become significant in the children development, in three different levels (similar to life stages): the game of exercise, the symbolic game and the game of rules.

From a problem, the researcher must be attending if it should/must be addressed through an empirical survey of quali-quantitative validation. The Discourse of Collective Subject (DCS) is a technique for qualitative-quantitative analysis and it aims to get the whole spectrum of possible opinions on the issues studied in the research population. Therefore, the selection of subjects must necessarily allow different opinions in the interviews universe. For this purpose, it should be chosen from all people ideas about the researched problem. Therefore, the composition of the population strata is very important to the research [6]. 
The work in this paper is part of a project which aims to study and to develop technologies that incorporate consumer of electricity as an element in grid consumption, considering the psychological aspects associated with the motivation of the individual to raise awareness of sustainable consumption. In this way, the consumer will no longer be a passive element and he/she will control the consumption and the variables involved. The project1 aims to contribute to technological, social and scientific development by user technologies as well as change their behavior in order to achieve rational consumption of electricity. In this paper, we present an analisys with six people about the game influence in their life and how games can change the attitudes of people. To do this analysis, we have conduct an interview with them, and their answers were tabulated using the Discourse of Collective Subject technique.

This paper is divided into 5 sections. Section 2 presents the theoretical basis of this work: Discourse of Collective Subject, Serious Games and Energy Consumption. In the Section 4 are presented the adopted methodology to our work. Section 4 presents the results (the discourses that we found from our subjects. Section 5 presents the conclusions and future work.

\section{Theoretical Basis}

\subsection{Discourse of Collective Subject (DCS)}

The proposal of the Discourse of Collective Subject (DCS) [6] is based mainly on the assumptions of the Social Representations Theory [7]. The DCS catalogs and associates a series of operations on the statements collected in empirical surveys through open questions, which at the end of the process result in collective statements that are made from extracts of different individual statements. Each of these collective statements has a specific and distinct opinion or position, and such statements written in the first person with the idea of producing the effect of a collective opinion [6].

The initial applications of DCS technique was health field. After, other areas became to use the collective opinions expression and processing. The aims of DCS is to demonstrate the self-expression of the collective thought or opinion, respecting the qualitative and quantitative condition of it. But how to express this collective subject as a "subject-totalk", and not as a mathematical expression [6]?

The collective subject cannot speak because, in Portuguese, the possibilities offered are precarious, just to access directly, the collective subject, which is the pronoun "we" of the plural first person, in the absence the alternative of "collective self". However, when the collectivity is expressed in the singular first person, and it illustrates the operation of the social representations system. In addition, the DCS is a feature that enables the social representations as collective facts inherent qualitative collectivity (speeches) and quantitative (of individuals), that is, individuals can share the same views but when such individuals opine individually may transmit only a portion of the view shared content [7].

A collective subject, the in DCS, tries to reconstitute a collective subject that, while collective person, is at the same time, speaking as if he/she was an individual, that is, as a "natural" speech subject, but linking to a representation with larger content.

\subsection{Serious Game}

The terms "game", "toy" and "joke" are sometimes used ambiguously. However, these concepts that enable recreational activities. The researchers do not have a homogeneous from the the "act to play" [8].

In a sociocultural perspective, the game is defined by how children interpret and understand the world, objects, culture and people. Therefore, it is childhood space to experience the adult world, with imaginative and diverse aspects, providing a unique opportunity for children [9].

Playing is a physical or mental activity organized by a system of rules. These rules define the loss/gain game [10]. The child builds the thought and language through games, because during the game he/she develops his/her experiences and organizes he/she cognitive processes.

"In the toy, the child always behaves beyond the usual behavior of his/her age, in addition to his/her daily behavior; the toy, he/she feels is larger than he/she really is. As a magnifying glass, the toy contains all the trends of development in condensed form, it even being a major source of development." [1].

The game, as simpler it is, requires fundamental motor skills as walking, running or jumping, and cognitive skills as perception, logical reasoning, rhythm or socialization that are used in our daily lives making easier motor and cognitive development, especially in children. The cognitive aspect refers to the development of the intellect during play activities. Children learn through play, increase their knowledge through partners and they can experience learning. When a child plays, he/she makes decisions (majority instant choices) thus making the game a basic element for the changing needs and consciousness [8].

However, to all these advantages could be used for educational purposes, the games must have clear learning objectives and teach the disciplines to users, or they must promote the development of strategies or important skills to expand the cognitive and intellectual ability of students [3]. 
The Serious Games is a game segment for teaching and learning [12]. They are defined as " a mental contest, played with a computer in accordance with specific rules, that uses entertainment to further government or corporate training, education, health, public policy, and strategic communication objectives" [13] p. 26. According Prensky [14], the learning based games goes beyond the traditional learning, because these type of games have the ambition to incorporate fun and enjoyment in the game experience, while learning elements are not so evident.

An effective serious game should take into account the intrinsic motivational ingredients like challenge, curiosity, fantasy and control [15]. Table 1 shows some difference between computer games for entertainment and serious games.

Table 1. Differences between entertainment games and serious games [16]

\begin{tabular}{|l|l|l|}
\hline Aspect & $\begin{array}{l}\text { Entertainment } \\
\text { Games }\end{array}$ & Serious Games \\
\hline $\begin{array}{l}\text { Task versus } \\
\text { rich } \\
\text { experience }\end{array}$ & $\begin{array}{l}\text { Rich } \\
\text { experiences } \\
\text { preferred }\end{array}$ & $\begin{array}{l}\text { Problem } \\
\text { solving } \\
\text { focus }\end{array}$ \\
\hline Focus & To have fun & $\begin{array}{l}\text { Important } \\
\text { elements } \\
\text { learning of }\end{array}$ \\
\hline Simulations & $\begin{array}{l}\text { Simplified } \\
\text { simulation }\end{array}$ & $\begin{array}{l}\text { Assumptions } \\
\text { necessary for } \\
\text { workable } \\
\text { simulations }\end{array}$ \\
\hline $\begin{array}{l}\text { Communicati } \\
\text { on }\end{array}$ & $\begin{array}{l}\text { Communication } \\
\text { is often perfect }\end{array}$ & $\begin{array}{l}\text { Should reflect } \\
\text { natural (i.e. } \\
\text { non-perfect) } \\
\text { communication }\end{array}$ \\
\hline
\end{tabular}

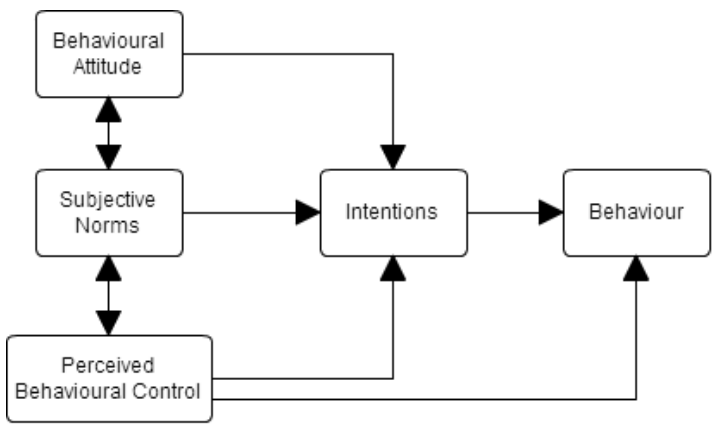

Figure 1. Schematic presentation of main parts of the Theory of Planned Behavior [19]

There are some attempts to change behavior in young people through a game based theories such as the Theory of Planned Behaviour (TPB) [17], [18]. TPB assumes that behavior/intuitive behavior are governed by the interaction of different psychological constructs. First among these is the Attitude towards Focal Behavior and constitutes the degree to which this particular behavior is valued: positively or negatively. Another influential variable is the Subjective Norm: the degree to which people think their social environment likes or wants them to perform the particular behavior. Finally, whether or not behavior will actually be performed also depends on the degree to which people believe they are able to perform the focal behavior: Perceived Behavioral Control. In short, a positive attitude towards a particular behavior in combination with positive subjective norms and a higher degree of perceived control will likely positively influence in a person (see Figure 1).

\section{Energy Consumption in Brazil}

The electricity consumption is a leading indicator of economic development and the quality life level in the society. However, electricity consumption data of individual consumer units is difficult to achieve for many reasons, as privacy issues [20].

From 2002 to 2011, electricity consumption had a significant growth of 270 toe - tons of oil equivalent, and it represents approximately $2 \%$ of world electricity consumption (Key world energy statistic, 2012). This consumption is almost the same form 2002 to 2011 production in Brazil (400 TW), that is equivalent to $10 \%$ of world production. The continuous growth of electricity consumption is increased the $\mathrm{CO} 2$ emissions into the atmosphere. However, Brazil is investing in renewable energy sources and these represent about $80 \%$ of production in the country (hydrological and wind) [20]. This factor contributed to Brazil has lower levels of $\mathrm{CO} 2$ emissions (about 1.43 tons of $\mathrm{CO} 2$ per toe) comparing to developed countries [21].

The Brazilian demand of electricity will increase at an average rate of $4.8 \%$ per year. Researchers expect a consumption, in 2020, of 730.1 Gwh per year. These estimates appear in Technical Notes of Brazilian Energy Research Company, called "Projection of the Electric Energy Demand for the Next Ten Years". From residential consumers, the average consumption will increase from 154 $\mathrm{kWh} /$ month in 2010 to $191 \mathrm{kWh} /$ month in 2020 . In 2001, a historic value of consumption of 180 $\mathrm{kWh} /$ month was observed, and it will be exceeded around 2017. The national energy consumption in the electric network in January 2011, as a total of $35,812 \mathrm{GWh}$, with an increase of $6.5 \%$ compared to the same period in 2010 [22].

The sustained growth of residential electricity consumption is consistent with the statistics released by Brazilian Geographic Institute, where the sale of "furniture and appliances" (increased $18.3 \%$ in 2010) and the study of data from IDC Brazil (International Data Corporation) that point the growth of $23 \%$ in sales of personal computers in the last years [22]. 


\section{Methodology}

The purpose of this paper is the implementation of a sequence of steps described below. First, we have conducted an interview with six students of courses of computer science area at our university. The age average of them was 30 years old. In this interview, we have done seven questions:

- Which games you usually play?

- Do you play some logical game?

- How often do you play games?

- What do motivate you to play games?

- What is the type of game you usually play? Some non-digital game?

- Do you think that games can influence people to change their attitudes about some things, as reducing energy consumption?

- Do you think these kind of games can influence people to have a specific attitude?

All questions were tabulated and analyzed to identify main idea, and setting an anchor category (DCS methodology). Thereby, the analysis of the DCS can be carried out in order to better understand how students understand the issues related to the project.

\section{Results}

For the scope of this paper, here are presented the results of the questions 4, 6 and 7 of the questionnaire, i.e., "What do motivate you to play games?", "Do you think that games can influence people to change their attitudes about some things, as reducing energy consumption?" and "Do you think these kind of games can influence people to have a specific attitude?".

Tables 2, 3 and 4 show the obtained results, where in the "Key Expressions" column, the exact responses of students on the questionnaire are presented, respecting the tense verbs and original writings of them; in the "Central Ideas" column, there are the interpretation of the responses; and in the "Anchor" columns are the associated theories related with each central idea. For example, when a student says "Entertainment. It's fun and change a little my routine," and we put as a central idea "Entertainment", and the "Games and Entertainment" anchor.

Note that the DCS was composed in the singular first person, with the key expressions of similar speeches meaning from 6 (six) people, where 4 (four) were male and 2 (two) was female.

This collective person is talking as if it were an individual, i.e., as a discourse of the subject "natural", but it represents various individuals, allowing the emergence, both qualitative and quantitative, of a collective opinion: qualitative because it is a speech with expanded content, diversified for the construction of DCS. These answers have some orthographic mistakes that we kept exactly as they spoke, as the discourses presented.

Table 2.Tabulated responses of question 4

\begin{tabular}{|c|c|c|}
\hline Key Expression & $\begin{array}{l}\text { Central } \\
\text { Idea }\end{array}$ & Anchor \\
\hline $\begin{array}{l}\text { Ah... I do not know... it is a } \\
\text { complicated answer.... } \\
\text { What do motivate me to } \\
\text { play? Everybody has that a } \\
\text { moment, you know, where } \\
\text { you work all day, you } \\
\text { study all day and you } \\
\text { arrive home and you want } \\
\text { to see a soap opera... do } \\
\text { nothing. I like to play } \\
\text { because it relaxes me, it } \\
\text { motivates me. It is my } \\
\text { moment, I can drop } \\
\text { everything and I will have } \\
\text { my moment. I will play to } \\
\text { distract me, get out } \\
\text { worries... }\end{array}$ & $\begin{array}{l}\text { Entertain } \\
\text { ment }\end{array}$ & $\begin{array}{l}\text { Games and } \\
\text { Entertainm } \\
\text { ent }\end{array}$ \\
\hline $\begin{array}{l}\text { Entertainment. It is fun } \\
\text { and I can change a little } \\
\text { my routine. }\end{array}$ & $\begin{array}{l}\text { Entertain } \\
\text { ment }\end{array}$ & $\begin{array}{l}\text { Games and } \\
\text { Entertainm } \\
\text { ent }\end{array}$ \\
\hline Just to pass the time. & $\begin{array}{l}\text { Entertain } \\
\text { ment }\end{array}$ & $\begin{array}{l}\text { Games and } \\
\text { Entertainm } \\
\text { ent }\end{array}$ \\
\hline \multicolumn{3}{|l|}{ It is nice. I like, it is fun. } \\
\hline $\begin{array}{l}\text { Nowadays, I do not } \\
\text { motivate to play anymore, } \\
\text { but in the old days, I like to } \\
\text { organize game strategies, } \\
\text { ie, age of empires that I } \\
\text { played a lot. When you } \\
\text { organize a strategy, you } \\
\text { can win the game. Why I } \\
\text { do not motivate anymore } \\
\text { today? Because, I have a } \\
\text { lot of work to do. }\end{array}$ & $\begin{array}{l}\text { Do not } \\
\text { play } \\
\text { anymore } \\
\text { Game } \\
\text { Strategies }\end{array}$ & $\begin{array}{l}\text { Game } \\
\text { Strategies }\end{array}$ \\
\hline $\begin{array}{l}\text { To de-stress me a little, } \\
\text { because as much as you } \\
\text { dedicate yourself in the } \\
\text { game and it is logic game, } \\
\text { you are doing something } \\
\text { light, you must not have a } \\
\text { result. It is, when you play } \\
\text { some like it, you want to } \\
\text { win, but you do not need a } \\
\text { result as other things. }\end{array}$ & $\begin{array}{l}\text { Entertain } \\
\text { ment }\end{array}$ & $\begin{array}{l}\text { Games and } \\
\text { Entertainm } \\
\text { ent }\end{array}$ \\
\hline
\end{tabular}

Below, the DCS1 (Motivation to play games), which the speech represents all participants:

"I like to play, it is fun, it relaxes me, it motivates me, it is my moment, I can drop everything and I will have my moment. I will play to distract me, get out worries. To 
de-stress me a little, because as much as you dedicate yourself in the game and it is logic game, you are doing something light, you must not have a result. It is, when you play some like it, you want to win, but you do not need a result as other things."

\section{DSC1: The game as entertainment}

In the DCS1, we can observe that the use of games as entertainment which can be sustained by the immersion of this type of activity can do. In a game, when a person drives a car or open a castle door, he/she feels as if the his/her body and mind are entered into a new space. Therefore, the player feels free and interested in freely explore the environment interacting with the elements. In this selfrepresentation of himself/herself in a virtual scenario, the player feels pleasure through this immersion.

This sensation is related to the sense of control, as the player wants to act, do more a passive observer and be a protagonist who sees the result of his/her actions and choices. It allows the player to feel powerful and responsible, because where he/she could decide, for example, about the future of humanity? Or change the course of history? If the choices result in damage, he/she just start the game and goes through the same experience but making different choices, doing different.

Below, the DCS2 (Game as a behavior changer), which the speech represents all participants:

\begin{abstract}
"When you play logic games, as me, your brain is stimulated. Logic games make you really think and you have a more accurate logic. Then it will help with kids or teenagers, because they have an open mind and it becomes interesting and they will take it for their life. In this way, a game can help to reduce power consumption and it consequently leads a change. But, the game must prove that it really is true, then the person will change his/her attitudes."
\end{abstract}

\section{DSC2: Game as a behavior changer}

In the DCS2, we can observe that games are efficient tools for better understanding about contents, contributing to the better citizens [8]. Among them, we can emphasize the cooperative games that are structured games where the pressure to compete and the need for destructive behavior could be decreased. They can be used to promote interaction and participation, through dialogue and a consensus decision-making. In this way, we will have collective work.
The games produce changes in cognitive skills of learners, especially the ability to process a larger amount of information and learn through experimentation and quick actions. According to Dempsey, Haynes, Lucassen \& Casey [23], games also develop deductive reasoning, memorizing strategies and visual and motor coordination.

Below, the DCS3 (The game as a specific changer), which the speech represents all participants:

"I think that a game can incentive the reduction of energy consumption, it could help to change a person's attitude. A game can influence the changing attitudes of a person. I think that when a person likes to play, he/she totally changes his/her attitudes, he/she changes his/her social life. The competitive games will make you make more competitive compared to others, while the collaborative game you will develop relationship strategies, to work as a team. The exact moment that you have a person to share an idea, or to interact, you will transmit messages more easily in a nicer way. The cooperative work will pass the idea that together we do more! However, change behavior is very complex concept, then in some situations, it could work, but the game must be very elaborate. In this way, it is difficult to have a game that will influence a person enough to change some attitude".

\section{DSC3: The game as a specific changer}

In the DCS3, we can observe that games must be more elaborated to have success. However, according Souza and Vieira [8], the cognitive aspect refers to the development of the intellect during play activities. Children learn through play and increase their knowledge through partners. When a child plays he/she makes decisions, these choices are immediate. In this way, the game is a basic element for the changing needs and consciousness.

In addition, [3] reinforces the idea that educational purposes of the game (they must have clear objectives, they must teach contents of disciplines and they must promote the development of strategies/important skills to expand the cognitive and intellectual ability of students). 
Table 3. Tabulated responses of question 6

\begin{tabular}{|c|c|c|}
\hline Key Expression & Central Idea & Anchor \\
\hline $\begin{array}{l}\text { The game can have a bias, and some people say that games have } \\
\text { problems as increased violence. I think they may have a issue to aware, } \\
\text { a game that talks about environment it is interesting, whereas he/she } \\
\text { will play because his/her is showing and after he/she continues to play, } \\
\text { but I do not know if it will work in real life. In the case of power } \\
\text { consumption, a game that encourages lower energy consumption. I do } \\
\text { not know if a game, that more fun as can do, I not know if it will } \\
\text { change so directly, but I think I can help do it. I think if } 10 \text { people } \\
\text { play, may be } 9 \text { will not see the main idea. I think it will help with kids } \\
\text { or teenagers, because they have an open mind and it becomes } \\
\text { interesting and they will take it for their life. It is easier for them than } \\
\text { to a person as me, sure. So that for sure. }\end{array}$ & $\begin{array}{l}\text { Behavior change } \\
\text { Influence of games in children's } \\
\text { lives }\end{array}$ & Games Influence \\
\hline $\begin{array}{l}\text { I think it might be possible. I do not know how it can happen, but I } \\
\text { think it is possible. } \\
\text { When you play logic games, as me, your brain is stimulated, right? } \\
\text { And you have a different behavior, I believe, as compared with action } \\
\text { games. These kinds of games make you really think and you have a } \\
\text { more accurate logic. }\end{array}$ & $\begin{array}{l}\text { Behavior change } \\
\text { Game Strategies }\end{array}$ & Games Influence \\
\hline $\begin{array}{l}\text { No, I do think not, because the person's behavior is more influenced by } \\
\text { the external environment, the society. The games cannot change } \\
\text { behaviors, or I do not see a game as that. Perhaps for the children, } \\
\text { because they are grouping up. }\end{array}$ & $\begin{array}{l}\text { Influence of games in children's } \\
\text { lives }\end{array}$ & Games Influence \\
\hline No, because people just play to have fun. & Entertainment & $\begin{array}{l}\text { Games and } \\
\text { Entertainment }\end{array}$ \\
\hline $\begin{array}{l}\text { I think that a game can help to reduce power consumption and it } \\
\text { consequently leads a change. But, you must prove that it really is true, } \\
\text { you can change the person's attitudes. I think a game could do it. } \\
\text { I think the motivation theory talk about it, right? When you give a } \\
\text { reward anyone, you can receive something back. }\end{array}$ & Behavior change & Games Influence \\
\hline $\begin{array}{l}\text { Yes, I think. I think you have to show people by a game the ways that } \\
\text { he/she can change things as it can reduce things, if it is advantageous } \\
\text { for him/her as a financial reward, then you can interfere in the } \\
\text { person's behavior. }\end{array}$ & Behavior change & Games Influence \\
\hline
\end{tabular}

In addition, [3] reinforces the idea that educational purposes of the game (they must have clear objectives, they must teach contents of disciplines and they must promote the development of strategies/important skills to expand the cognitive and intellectual ability of students).

Table 4. Tabulated responses of question 7

\begin{tabular}{|c|c|c|}
\hline Key Expression & $\begin{array}{l}\text { Central } \\
\text { Idea }\end{array}$ & Anchor \\
\hline $\begin{array}{l}\text { Yes, I think so, we will } \\
\text { see it. In the case of } \\
\text { energy consumption, it } \\
\text { becomes easier in the } \\
\text { exact moment that you } \\
\text { have a person to share an } \\
\text { idea, or to interact. In } \\
\text { this way, I think you will } \\
\text { transmit messages more } \\
\text { easily in a nicer way. } \\
\text { Then, I think so. The } \\
\text { cooperative work could } \\
\text { help to change a person's } \\
\text { attitude. Yes! In addition, }\end{array}$ & $\begin{array}{l}\text { Behavior } \\
\text { change }\end{array}$ & $\begin{array}{l}\text { Games } \\
\text { Influence }\end{array}$ \\
\hline
\end{tabular}

\begin{tabular}{|l|l|l|}
\hline $\begin{array}{l}\text { it will pass the idea that } \\
\text { together we do more! }\end{array}$ & \\
\hline $\begin{array}{l}\text { I think that competitive } \\
\text { and collaborative games } \\
\text { can be useful, with } \\
\text { different kinds of results. } \\
\text { The competitive games } \\
\text { will make you make } \\
\text { more competitive } \\
\text { compared to others, } \\
\text { while the collaborative } \\
\text { game you will develop } \\
\text { relationship strategies, to } \\
\text { work as a team. }\end{array}$ & $\begin{array}{l}\text { Game } \\
\text { Strategies }\end{array}$ & \\
\hline $\begin{array}{l}\text { Change behavior is very } \\
\text { complex concept, then in } \\
\text { some situations, it could } \\
\text { work, but the game must } \\
\text { be very elaborate. Until } \\
\text { now, } \text { do not know a } \\
\text { game as it. }\end{array}$ & \\
\hline $\begin{array}{l}\text { No. Because I have } \\
\text { spoken before. It is } \\
\text { difficult ho have a game } \\
\text { that will influence a } \\
\text { person enough to change }\end{array}$ & Behavior \\
change & Games \\
Influence \\
Influence \\
\end{tabular}




\begin{tabular}{|c|c|c|}
\hline some attitude. Just it. & & \\
\hline $\begin{array}{l}\text { I think so.. A game can } \\
\text { influence the changing } \\
\text { attitudes of a person. I } \\
\text { think that when a person } \\
\text { likes to play, he/she } \\
\text { totally changes his/her } \\
\text { attitudes, he/she changes } \\
\text { his/her social life. }\end{array}$ & $\begin{array}{l}\text { Behavior } \\
\text { change }\end{array}$ & $\begin{array}{l}\text { Games } \\
\text { Influence }\end{array}$ \\
\hline $\begin{array}{l}\text { I think it will not } \\
\text { transform anyone, but } \\
\text { you can indeed arouse } \\
\text { some interest, but there } \\
\text { are two sides, right? You } \\
\text { spoke about violence. A } \\
\text { guy will not go out } \\
\text { shooting people because } \\
\text { the game was shooting. } \\
\text { However, he can have a } \\
\text { motivation and do bad } \\
\text { things, I know, nobody is } \\
\text { obliged to do something, } \\
\text { but he can arouse his } \\
\text { interest in this kind of } \\
\text { things. }\end{array}$ & $\begin{array}{l}\text { Behavior } \\
\text { change }\end{array}$ & $\begin{array}{l}\text { Games } \\
\text { Influence }\end{array}$ \\
\hline
\end{tabular}

\section{Conclusions}

Educational processes are under constant change over the years, boosted by techniques and tools that come with the intention of adding ways to improve the absorption of knowledge presented, and also provide more effective, dynamic and diverse forms of learning. Games can facilitate the cognition, develop skills and beliefs on topics through practical experimentation, eliminating the need for tactile features that were necessary for the study of the processes involved in real environments.

The Discourse of Collective Subject aims to show a thought or collective opinion from a group, based on a qualitative condition (individual opinions) and quantitative (group ideas).

Based in these two premises, this paper presented an analysis of three questions from an applied questionnaire to a group of students about the game influence in their life and how games can change the attitudes of people. In the DCS1, we can see that games are in daily life of these students, as an entertainment. Therefore, the players could make decisions without any damage, and in this way, "live other life".

DCS2 shows us that games are efficient tools to learn about serious things, besides they promote interaction and participation, and they help in cognitive skills. Thereby, we can conclude that games can help to change attitudes.

In the DCS3, the students think that a game just could influence people to have specific attitudes when this game is elaborate/complex. However, some researchers affirm that any game could help in the learning process and it could help to change attitudes (or increase the knowledge). May be, these students just think that games are to entertain, not to learn (as they answered in DCS1).

For a better understanding, we must to more interviews and discover what the students think about games. After this analysis, a new question shows up for us: this younger generation is so familiarized with games, and they do not bring more impact on education? Do the students perceive the games only as entertainment?

\section{References}

[1] J. Valente, F.M.P. Freire, H.V. Rocha, J.V. D’a Breu, M.C.C. Baranauskas, M.C. Martins and M. E.B.B. Prado., "O computador na sociedade do conhecimento", Coleção informática para a mudança na educação, 1998.

[2] J.A Valente., "Informática na Educação no Brasil Análise e Contextualização Histórica", O computador na sociedade do conhecimento. Brasília: MEC, 11-28, 1998.

[3] B. Gros., "The impact of digital games in education", First Monday, v. 8,2003, http://www.firstmonday.org/ issues/issue8_7/xyzgros/index.html.

[4] G. Aranha., "Jogos Eletrônicos Como um Conceito Chave para o Desenvolvimento de Aplicações Imersivas e Interativas para o Aprendizado", Ciências e Cognição, Ano 03, Vol. 07, 2006.

[5] J. Piaget., "A formação do símbolo na criança: imitação, jogos, sonho, imagem e representação", $3^{\text {a }}$ edição, Rio de Janeiro: Editora Koogan, 1978.

[6] F. Lefevre and A.M.C. Lefevre., "O discurso do sujeito coletivo: um novo enfoque em pesquisa qualitative", Desdobramentos, Educs, 2003.

[7] F. Lefevre and A.M.C. Lefevre. "O sujeito Coletivo que fala", Interface - Comunic, Saúde, Educ, v.10, numero 20, pp. 517-524, 2006.

[8] A.P.D. Souza and J.J. Vieira., "A Importância do Brincar e do Jogar nas Séries Iniciais", FIEP Bulletin Online, 80(2), 2010.

[9] B. Bettelheim., "Uma Vida Para Seu Filho". Rio de Janeiro. Campos. Tradução Maura Sardinha e Maria Helena Geordane, 1988.

[10] E. Bomtempo., "Aprendizagem e brinquedo", Psicologia da aprendizagem: Áreas e aplicação, São Paulo: Editora Pedagógica Universitária, pp. 15-27, 1987.

[11] L.S. Vygotsky., "A formação social da mente", $6^{\mathrm{a}}$ edição, São Paulo: Martins Fontes, pp.117, 1998.

[12] L.A. Annetta., "Video games in education: Why they should be used and how they are being used", Theory into practice 47.3: pp. 229-239, 2008.

[13] M. Zyda., "From visual simulation to virtual reality to games", Computer, 38(9), pp.25-32, 2005. 
[14] M. Prensky., "Digital Natives, digital immigrants", 2015, http://www.marcprensky.com/writing/Prensky\%20$\% 20$ Digital\%20Natives, \%20Digital\%20Immigrants\%20\%20Part1.pdf., 2001, Accessed: December, 2015.

[15] L.P. Rieber., "Seriously considering play: Designing interactive learning environments based on the blending of microworlds, simulations, and games", Educational Technology Research and Development, 44(2), pp. 43-58, 1996.

[16] T. Susi., M. Johannesson. and P. Backlund., "Serious games: An overview School of Humanities and Informatics", University of Skovde, Sweden, Tech. Rep, 2005

[17] I. Ajzen and M. Fisbbein., "Factors influencing intentions and the intention-behavior relation", Human Relations, 27(1), pp. 1-15, 1974.

[18] I. Ajzen and M. Fisbbein., "Understanding attitudes and predicting social behavior", Engle-wood-Cliffs, N.J.: Prentice-Hall, 1980.

[19] I. Ajzen., "From intentions to actions: A theory of planned behavior", Springer Berlin Heidelberg, pp. 11-39, 1985.

[20] EPE., "Balanço Energético Nacional 2012. Empresa de Pesquisa Energética (EPE)", Ministério de Minas e Energia (MME), Rio de Janeiro, 2012.

[21] MME., "Resenha energetica brasileira, exercicio de 2011”, 2011,http://www.biblioteca.presidencia.gov.br/ publicacoes-oficiais-1/catalogo/conselhos/conselhonacional-de-politica-energetica/resenha-energeticabrasileira-exercicio-de-2011-resultados-preliminares/ view, Accessed: January, 2014.

[22] L. Mendonça., "Consumo de energia deve crescer $4,8 \%$ até $2020 ", 2015$, http://www.osetoreletrico.com.br/ web/a-empresa/532-consumo-de-energia-deve-crescer-48ate-2020.html, Accessed: December, 2015.

[23] J.V. Dempsey, L.L. Haynes, B.A. Lucassen and M.S. Casey., "Forty simple computer games and what they could mean to educators". Simulation \& Gaming, 33(2), pp. 157-168, 2002. 